\title{
Pengembangan Lembar Kerja Peserta Didik Berbasis Problem Solving Materi Bangun Datar Muatan Matematika Pada Siswa Kelas IV SD
}

\author{
I Putu Alvin Pradiptha ${ }^{1 *}$, I Wayan Wiarta ${ }^{2}$ \\ ${ }^{1,2}$ Universitas Pendidikan Ganesha, Singaraja, Indonesia \\ *Corresponding author: putualvinpradiptha@gmail.com
}

\begin{abstract}
Abstrak
Kurangnya sumber belajar sebagai fasilitas dalam kegiatan pembelajaran,mengakibatkan sulitnya siswa dalam memahami materi. Penelitian ini bertujuan untuk menganalisis rancang bangun dan kualitas dari LKPD berbasis Problem solving pada pelajaran matematika muatan materi bangun datar. Jenis nenelitian ini adalah penelitian pengembangan menggunakan model ADDIE dengan tahapan analyse, design, development, implementation dan evaluation. Subjek uji coba produk yaitu 3 orang ahli pelajaran, desain, dan media. Tahap uji coba dilakukan melalui uji coba perorangan dengan 3 orang. Analisis data dilakukan dengan teknik analisis deskriptif kuantitatif dan analisis deskriptif kualitatif. Setelah diperoleh persentase melalui beberapa tahap uji dan selanjutnya dikonversikan dengan tabel konversi tingkat pencapaian skala 5 didapatkan hasil persentase review ahli isi mata pelajaran dengan presentase 92\%, ahli desain 90\%, dan ahli media yaitu $93 \%$ dengan kualifikasi sangat baik. Sedangkan hasil uji coba peorangan yaitu 93,33\%. Sehingga kualifikasi yang didapat sangat baik. Hal ini menunjukkan bahwa LKPD yang dikembangkan sudah memenuhi syarat. Jadi dapat disimpulkan bahwa, pengembangan produk LKPD Berbasis Problem Solving sangat baik dan layak digunakan.
\end{abstract}

Kata kunci: Matematika, Problem Solving, LKPD

\section{Abstract}

Lack of learning resources as facilities in learning activities, resulting in difficulty for students to understand the material.. This study aims to analyze the design and quality of student worksheet based on problem solving in mathematics subject matter content of flat shapes. This type of research is development research using the ADDIE model with the stages of analysis, design, development, implementation and evaluation. The subjects of the product trial were 3 subject, design, and media experts. The trial phase was carried out through individual trials with 3 people. Data analysis was performed using quantitative descriptive analysis techniques and qualitative descriptive analysis. After obtaining it through several stages of testing and then being converted to a scale scale 5 conversion table, the results of the proportion of subject content expert reviews with a presentation of $92 \%$, design experts $90 \%$, and media experts are $93 \%$ with very good qualifications. While the results of individual trials were $93.33 \%$. The qualifications obtained are very good. This shows that the developed LKPD has met the requirements. So it can be denied that the product development of LKPD based on Problem Solving is very good and feasible to use.

Keywords: Mathematics, Problem Solving, LKPD

$$
\begin{aligned}
& \text { History: } \\
& \text { Received : } 3 \text { Januari } 2021 \\
& \text { Revised : } 3 \text { Februari } 2021 \\
& \text { Accepted : } 1 \text { Maret } 2021 \\
& \text { Published : } 25 \text { Maret } 2021
\end{aligned}
$$

Publisher: Undiksha Press

Licensed: This work is licensed under

a Creative Commons Attribution 4.0 License

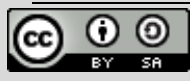

\section{Pendahuluan}

Pembelajaran matematika yang berkualitas merupakan usaha yang kompleks untuk membantu semua siswa belajar atau membantu semua guru menjadi efektif (Laswadi, 2016) Matematika merupakan ilmu yang diajarkan pada setiap jenjang pendidikan (Crismono, 2017). Pada muatan pembelajaran matematika memiliki standar-standar kemampuan yang harus dikuasai peserta didik. Standar-standar kemampuan matematis itu meliputi: pemecahan 
masalah, penalaran dan pembuktian, komunikasi, koneksi, dan representasi (National Council of Teachers of Mathematics, 2000). Pembelajaran matematika memiliki tujuan untuk mengembangkan kemampuan memecahkan masalah dan menyajikan gagasan/ide melalui lisan, tulisan, gambar, grafik, peta, diagram dan sebagainya (Depdiknas, 2006). Oleh karena itu, matematika memiliki struktur dan keterkaitan yang kuat serta jelas antar konsep, pembelajaran matematika mampu memberikan keterampilan dalam berpikir rasional dan siap menghadapi permasalahan dalam kehidupannya (Ayazgok, B., \& Aslan, 2014). Proses pembelajaran hendaknya memberikan kesempatan seluas-luasnya kepada peserta didik untuk memaknai setiap hal yang mereka pelajari melalui proses pemecahan masalah sehingga mereka memahami konsep-konsep dengan pengetahuan yang dimilikinya (Fimansyah, 2015).

Namun kenyataanya dilapangan proses pembelajaran matematika bisa dikatakan masih belum maksimal. Hal ini terbukti dari hasil survei PISA tahun 2018 khususnya untuk kategori matematika, Indonesia diurutan 73 dari 80 peserta yang mengikuti program ini dengan rerata skor 379. Rerata skor Indonesia masih sangat jauh bila dibandingkan dengan Cina yang berada pada peringkat pertama dengan rata-rata skor 591 (Permana, 2019). Mengacu pada data tersebut maka diperlukan proses pembelajaran yang inovatif khususnya pada muatan matematika. Salah satu alternatif yang bisa dilakukan adalah dengan memaksimalkan penggunaan perangkat pembelajaran khususnya Lembar Kerja Peserta Didik (LKPD). LKPD merupakan lembar kerja bagi peserta didik sehingga pembelajaran menjadi terpusat pada aktifitas peserta didik atau beralih dari teacher centered menjadi student centered (Anggraini et al., 2016; Effendi, Refki ., Herpratiwi, 2021). LKPD menjadi sarana penunjang pembelajaran yang berisi materi singkat, petunjuk praktikum, percobaan yang bisa dilakukan dirumah, materi diskusi, tugas portofolio, latihan soal yang bervariasi dan bersifat kontekstual (Hamidah et al., 2018; Sasmito \& Mustadi, 2015). LKPD merupakan lembar kerja bagi peserta didik sebagai penunjang proses pembelajaran yang bersifat kontekstual dan menantang sehingga terwujud suasana pembelajaran students centred.

Pengembangan LKPD hendaknya dipadukan dengan model pembelajaran yang sesuai dengan materi pembelajaran dan juga karakteristik peserta didik. Penyusunan dan penggunaan perangkat pembelajaran hendaknya diselaraskan dengan model, metode, atau pendekatan pembelajaran yang digunakan karena hal ini akan bepengaruh terhadap ketercapaian tujuan pembelajaran itu sendiri (Salim Nahdi \& Cahyaningsih, 2018). Salah satu model pembelajaran yang sesuai digunakan adalah model pembelajaran problem solving . Penyusunan LKPD dapat dilakukan melalui memadukannya dengan model problem solving merupakan salah satu inovasi pengembangan perangkat pembelajaran (Nurliawaty et al., 2017). Model pembelajaran problem solving merupakan model pembelajaran pemecahan masalah dengan tujuan dapat mengembangkan keterampilan berpikir tingkat tinggi melalui sebuah permasalahan yang harus dipecahkan oleh peserta didik (Afifah et al., 2019; Bey \& Asriani, 2013; Firli et al., 2017). Problem solving ditekankan sebagai aspek penting dan sangat berguna dalam menciptakan pengajaran matematika yang efektif (Laswadi, 2016). Selain itu, melalui penerapan model pembelajaran Problem Solving peserta didik menjadi pembelajar yang lebih aktif, keaktifan ini terjadi karena peserta didik memiliki tanggung jawab kepada masing-masing kelompoknya untuk mencari alternatif penyelesaian masalah yang diberikan. Peserta didik dilatih untuk berdiskusi dengan anggota kelompoknya guna memperoleh strategi yang tepat untuk memecahkan masalah (Handayani et al., 2018; Hariawan et al., 2014; Syazali, 2015; Warimun, 2017).

Temuan bebeerapa penelitian pengembangan LKPD Matematika berbasis Problem Based Learning yang menyatakan layak digunakan. Temuan penelitian pengembangan materi LKPD berbasis PBL di Sekolah Dasar sangat layak untuk digunakan dalam 
pembelajaran (Effendi, Refki ., Herpratiwi, 2021). Temuan lain menyatakan LKPD berbasis Problem Based Learning untuk melatihkan keterampilan berpikir kritis pada materi larutan penyangga yang layak digunakan(Jawadiyah, 2021; Ristiasari et al., 2012) (Jawadiyah, 2021). LKPD berbasis Problem Based Learning untuk melatih ketrampilan berpikir kritis dinyatakan layak digunakan untuk melatih ketrampilan berpikir kritis pada mata pelajaran sejarah kelas xi ips (Pangastuti, 2021). Penggunaan model pembelajaran problem solving juga didasari oleh beberapa penelitian sebelumnya yang memberikan hasil positif, yaitu menunjukan adanya pengaruh model pembelajaran problem solving terhadap hasil belajar peserta didik (Darmawan Harefa, 2020). Melalui penerapan model pembelajaran problem solving dapat meningkatkan kemampuan komunikasi matematis peserta didik (Hodiyanto, 2017).

LKPD yang ada di kelas IV di SD Negeri 4 Dalung pada materi bangun datar belum menampilkan keterampilan yang harus dikuasai siswa yaitu salah satunya keterampilan menyelesaikan masalah yang berkaitan dengan materi bangun datar. Mengingat pentingnya LKPD dalam proses pembelajaran khususnya pada muatan matematika maka perlu diperhatikan kualitas dari segi isi, desain, media dan metode pengembangannya. Melalui LKPD berbasis Problem Based Learning pada materi bangun datar siswa dalam pembelajaran dapat ditingkatkan, penyampaian materi pelajaran dapat dipermudah dengan menggunakan LKPD. Berdasarkan uraian tersebut maka dilakukan penelitian pengembangan LKPD berbasis Problem solving Materi Bangun Datar Muatan Matematika Pada Siswa Kelas IV Sekolah Dasar.

\section{Metode}

Penelitian ini bertujuan untuk mengetahui efektivitas LKPD berbasis Problem solving pada pelajaran matematika muatan materi bangun datar. Penelitian ini adalah penelitian pengembangan yang menggunakan model ADDIE dengan tahapan (1) analyze (2) design (3) development (4) implementation (5) evaluation. Subjek uji coba produk pada penelitian terdapat beberapat tahap yaitu tahap review para ahli dengan 3 orang ahli media, desain, dan materi dengan tujuan untuk memperoleh saran, masukan dan komentar yang akan dijadikan acuan untuk dapat menyempurnakan produk yang telah dikembangkan serta siswa kelas IV yang berjumlah 12 orang. Tahap uji coba dilakukan melalui uji coba perorangan dengan 3 orang. Analisis data dilakukan dengan teknik analisis deskriptif kuantitatif dan analisis deskriptif kualitatif. Setelah diperoleh persentase melalui beberapa tahap uji dan selanjutnya dikonversikan dengan tabel konversi tingkat pencapaian skala 5.

\section{Hasil dan Pembahasan}

Penelitian ini dilaksanakan pada kelas IV di SD Negeri 4 Dalung. Adapun pengembangan Lembar Kerja Peserta Didik (LKPD) Berbasis Problem Solving Materi Bangun Datar Muatan Matematika ini dilakukan dengan menggunakan model ADDIE, yaitu Tahap pertama, yakni tahap analisis (analyze). Dalam penelitian ini terdapat 3 jenis analisis yaitu analisis kebutuhan dimana pada tahap ini dilakukan untuk mengetahui kebutuhan yang diperlukan siswa dalam proses pembelajaran, analisis konten dilakukan untuk mengetahui materi yang akan digunakan serta melakukan analisis kompetensi dasar dan indikator untuk mengetahui kompetensi yang harus dicapai siswa pada saat pembelajaran. Setiap tahapan tersebut tersebut dilakukan dengan kegiatan observasi dan wawancara bersama guru kelas IV SD dengan tujuan untuk mengetahui kendala yang dihadapi oleh sekolah terkait dengan proses pembelajaran yang dilaksanakan sehingga peneliti menemukan bahwa media yang cocok untuk di kembangkan ialah media video animasi. Berdasarkan hasil wawancara diperoleh informasi bahwa guru mengalami permasalahan dalam pembelajaran matematika 
untuk mengembangkan LKPD yang dapat membantu siswa dalam memahami konsep matematika pada materi bangun data, pada pembelajaran guru hanya menggunakan buku sebagai sumber belajar yang menyebabkan siswa kesulitan memahami materi bangun datar.

Tahap kedua, yakni tahap perancangan (design). tahap perencanaan dihasilkan rancangan awal LKPD dengan memuat sub materi bangu ruang. LKPD ini memuat indikator keterampilan matematika yang meliputi interpretasi, inferensi dan analisis dengan menyesuaikan tahapan model PBL. Pada tahap ketiga dilakukan proses pengembangan LKPD yang didasarkan pada hasil rancangan yang telah dibuat. Tahap pengembangan dilakukan pengembangan LKPD yang diawali dengan (a) membuat desain tampilan awal LKPD, desain tampilan materi dan desain tampilan evaluasi. Cover utama LKPD didesain dengan tampilan sederhana, hanya menampilkan jenjang sekolah, dan nama untuk memudahkan proses pengumpulan. Jika LKPD selesai dikembangkan tahap selanjutnya melaksanakan uji coba produk pada subjek uji yang meliputi ahli isi pembelajaran, ahli desain pembelajaran, ahli media pembelajaran dan siswa melalui uji coba perorangan.

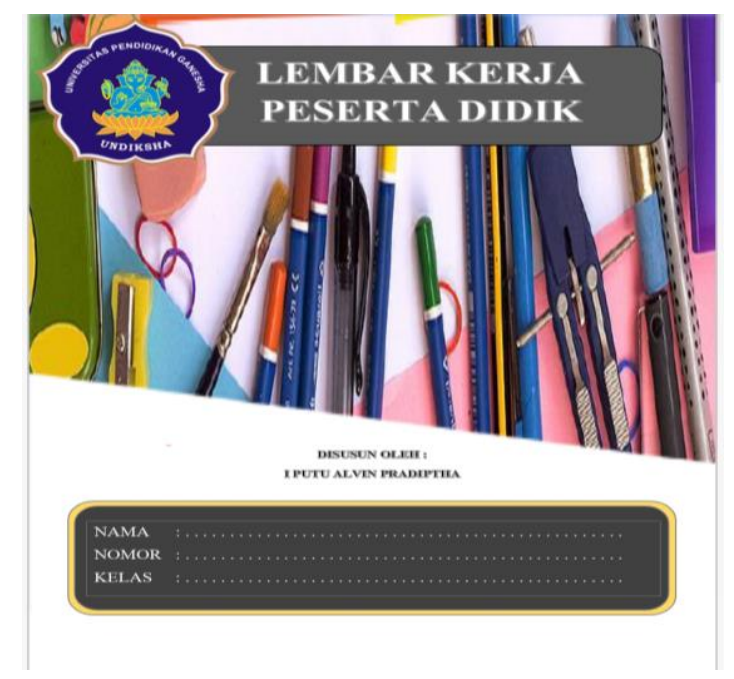

Gambar 1. LKPD Berbasis Problem Solving

Pada hasil analisis data terhadap pengembangan Lembar Kerja Peserta Didik (LKPD) Berbasis Problem Solving yang akan menunjukkan satu hal berkaitan dengan hasil evaluasi produk, yaitu analisis hasil validitas pengembangan Lembar Kerja Peserta Didik (LKPD) Berbasis Problem Solving. Adapun hasil analisis data tersebut akan dipaparkan pada table 1 sebagai berikut.

Tabel 1. Ringkasan Hasil Validitas Pengembangan Lembar Kerja Peserta Didik (LKPD) Berbasis Problem Solving.

\begin{tabular}{llll}
\hline No & Subjek Uji Coba & Hasil Validitas & Keterangan \\
\hline 1 & Isi Mata Pelajaran & $92 \%$ & Sangat Baik \\
2 & Uji Desain Pembelajaran & $90 \%$ & Sangat Baik \\
3 & Uji Media Pembelajaran & $93 \%$ & Sangat Baik \\
4 & Uji Perorangan & $93,33 \%$ & Sangat Baik \\
\hline
\end{tabular}

Berdasarkan hasil review oleh ahli isi mata pelajaran, Lembar Kerja Peserta Didik (LKPD) Berbasis Problem Solving ini memperoleh persentase yaitu 92\% yang berada pada kualifikasi sangat baik. Hal tersebut diperoleh dari beberapa hal yaitu: 1) Aspek kurikulum 2) 
Aspek materi dan 3) Aspek kebahasaan. Dalam aspek kurikulum meliputi beberapa hal seperti materi yang disajikan LKPD sesuai dengan kompetensi dasar, indikator, dan tujuan pembelajaran. Dalam aspek materi meliputi materi yang disajikan pada LKPD sesuai dengan cakupan materi pembelajaran, materi mudah dipahami dan latihan soal yang disajikan pada LKPD dapat melatih kemampuan berpikir tingkat tinggi (HOTS). Pada aspek kebahasaan meliputi konsistensi penggunaan kata dalam kalimat, kesusaian bahasa, ejaan yang sesuai dengan KBBI, struktur kalimat yang sudah tepat, dan kalimat tidak menimbulkan makna ganda. Dilihat dari aspek penilaian kesesuaian tujuan dengan materi yang disampaikan sudah sesuai dengan tujuan pembelajaran dan kurikulum yang digunakan di SD Negeri 4 Dalung adalah Kurikulum 2013.

Berdasarkan hasil review ahli desain pembelajaran memperoleh persentase yaitu $90 \%$ yang berada pada kualifikasi sangat baik. Untuk tercapai hal tersebut dipengaruhi oleh beberapa hal yaitu (1) Aspek tujuan, (2) Aspek strategi, (3) Aspek Evaluasi. Dalam Aspek tujuan meliputi beberapa hal seperti tujuan pembelajaran yang disajikan LKPD konsisten dengan materi. Dalam aspek strategi meliputi media LKPD dapat menarik dan memotivasi siswa. Pada aspek evaluasi meliputi soal yang disajikan dalam LKPD sesuai dengan indikator pembelajaran.

Berdasarkan hasil review ahli desain pembelajaran memperoleh persentase yaitu 93\% yang berada pada kualifikasi sangat baik. Untuk tercapai hal tersebut dipengaruhi oleh beberapa hal yaitu (1) Aspek teknis, (2) Aspek konstruksi, (3) Aspek metode. Dalam Aspek teknis meliputi beberapa hal seperti kesesuaian media LKPD dengan tujuan dan karakteristik siswa. Dalam aspek konstruksi meliputi ketepatan penggunaan bahasa, memperhatikan kemapuan siswa, dan memiliki manfaat. Pada aspek metode meliputi proses pembelajaran dalam LKPD tepat dan pengembangan kemampuan dalam LKPD tepat. Setelah melewati uji ahli, kemudian produk dapat di uji cobakan kepada siswa. Tahap uji coba ini terdiri dari satu tahap yaitu uji coba perorangan. Jika di review kembali persentase dari uji coba perorangan yang melibatkan 3 responden sebesar 93,33\% dengan kualifikasi sangat baik.

Berdasarkan hasil penelitian, pengembangan lembar kerja peserta didik berbasis problem solving memperoleh kualifikasi sangat baik, sehingga lembar kerja peserta didik berbasis problem solving layak digunakan pada proses pembelajaran. Dari segi penggunanaan lembar kerja peserta didik, pada saat penggunaan LKPD materi bangun datar, ada hal yang ditemukan saat proses pembelajaran berlangsung, di antaranya sebagai berikut peserta didik aktif dan sangat antusias memecahkan masalah sesuai dengan prosedur kerja dalam LKPD sehingga pembelajaran yang menyenangkan dan bermakna tercapai serta materi lebih mudah dipahami. Penggunaan model Problem Solving membuat peserta didik terlatih untuk mengembangkan keterampilan berpikir tingkat tinggi melalui pemecahan masalah pembelajaran menjadi semakin bermakna (Fitriyanto et al., 2012; Nopitasari, 2016; Purwanti \& Manurung, 2015; Puspita et al., 2018; Tampubolon \& Sitindaon, 2013).

Jika dilihat dari segi materi yaitu kesesuaian materi dengan kurikulum yang berlaku, materi pada LKPD sesuai dengan Kompetensi Inti (KI) dan Kompetensi Dasar (KD) dalam kurikulum 2013. Pembelajaran melalui Lembar Kerja Peserta Didik (LKPD) membuat peserta didik belajar menjadi lebih mudah karena materi yang disajikan berifat ringkas, sistematis dan dilengkapi dengan contoh penerapan konsep. Pembelajaran lebih sistematis karena LKPD yang disusun berisikan pentunjuk-pentujuk yang harus dilaksanakan peserta didik. Untuk karakteristik pendekatan problem solving yaitu mencakup langkah pembelajaran berbasis masalah yang terdiri atas orientasi masalah, mengorganisasi penyelidikan, investigasi masalah, merumuskan pemecahan, dan mengevaluasi atau menyimpulkan untuk melatih kemampuan analisis serta pemecahan masalah agar menghasilkan suatu keputusan yang tepat. Lembar Kerja Peserta Didik (LKPD) merupakan suatu bahan ajar cetak yang 
berupa suatu materi, ringkasan dan petunjuk pelaksanaan tugas pada pembelajaran yang harus dikerjakan oleh peserta didik yang mengacu pada kompetensi dasar (KD) (Prastowo, 2016) Dengan demikian melalui kegiatan tersebut peserta didik dapat melatih ketrampilan berpikir kritis pada materi bangun datar.

Jika dilihat dari segi desain, LKPD ini didesain agar peserta didik lebih aktif dalam proses pembelajaran serta dapat mengkosntruksi pengetahuan melalui kegiatan-kegiatan yang diberikan dalam LKPD. Kalimat yang digunakan lebih sederhana pada tujuan pembelajaran di LKPD, pada prosedur kegiatan menggunakan menggunakan tahapan model problem solving, LKPD juga dilengkapi gambar pendukung materi bangun ruang agar peserta didik lebih memahami maksud dari tujuan pembelajaran yang akan dilakukan. Problem solving adalah suatu proses berpikir yang memahami kenyataan dalam mengambil keputusan, memecahkan masalah, dan menghasilkan sesuatu yang baru. LKPD merupakan sarana penunjang pembelajaran yang berisi materi singkat, petunjuk praktikum, percobaan yang bisa dilakukan dirumah, materi diskusi, tugas portofolio, latihan soal yang bervariasi dan bersifat kontekstual (Hamidah et al., 2018; Sasmito \& Mustadi, 2015). Pemecahan masalah dilakukan dengan cara yang ilmiah. Artinya, mengikuti kaidah keilmuan, seperti yang dilakukan dalam penelitian ilmiah (Pristiwanto, 2016).

Hasil penelitian yang diperoleh dari pengembangan lembar kerja peserta didik ini sesuai dengan temuan penelitian sebelumnya yang telah dilakukan menyatakan bahwa pengembangan LKPD Matematika berbasis Problem Based Learning layak digunakan pada proses pembelajaran (Effendi, Refki ., Herpratiwi, 2021). Selain itu, LKPD berbasis Problem Based Learning dapat melatihkan keterampilan berpikir kritis (Jawadiyah, 2021; Ristiasari et al., 2012; Pangastuti, 2021) Penggunaan model pembelajaran problem solving juga memberikan hasil positif, yaitu menunjukan adanya pengaruh model pembelajaran problem solving terhadap hasil belajar peserta didik serta meningkatkan kemampuan komunikasi matematis peserta didik (Darmawan Harefa, 2020; (H. Hodiyanto, 2017).

Lembar Kerja Peserta Didik (LKPD) Berbasis Problem Solving ini dikembangkan untuk membantu guru dalam proses pembelajaran, sebagai acuan bagi sekolah dan juga guru untuk mampu memaksimalkan penggunakan LKPD dalam pembelajaran matematika.. Selain itu, diharapkan Lembar Kerja Peserta Didik (LKPD) Berbasis Problem Solving ini dapat memotivasi siswa dalam mempelajari materi agar dapat memahami materi yang disampaikan dengan mudah. Produk LKPD matematika berbasis problem solving yang dikembangkan dalam penilaiannya secara umum berkualitas sangat baik dan dapat meningkatkan keterampilan berpikir kritis dan hasil belajar peserta didik, namun dalam pengembangannya masih memiliki beberapa kelemahan. Kelemahan itu terdapat pada skala uji coba produk, hanya dilakukan dalam skala kecil yang melibatkan 1 (satu) sekolah. Uji coba produk ini juga hanya dilakukan pada IV di SD Negeri 4 Dalung dengan jumlah 12 peserta didik yang mewakili tingkat kemampuan atas, sedang, dan bawah.

\section{Simpulan}

Berdasarkan peneparan hasil dan pembahasan dapat disimbulkan bahwa, hasil uji ahli isi mata pelajaran, ahli desain pembelajaran, ahli media pembelajaran, dan hasil uji coba perorangan, mendapatkan kualifikasi sangat baik dan tidak perlu direvisi. Artinya media pembelajaran layak digunakan hasil uji ahli media pembelajaran, dengan kualifikasi sangat baik dan tidak perlu direvisi. Jadi, kualitas Lembar Kerja Peserta Didik (LKPD) berbasis Problem solving Materi Bangun Datar Muatan Matematika Pada Siswa Kelas IV Sekolah Dasar secara keseluruhan adalah sangat baik. Adapun saran yang ingin dikemukakan yaitu: bagi siswa, agar lebih aktif belajar secara mandiri dan kreatif memanfaatkan (LKPD) berbasis Problem solving Materi Bangun Datar Muatan Matematika. Bagi guru, agar memanfaatkan LKPD berbasis Problem solving dalam membelajarkan Materi Bangun Datar Muatan 
Matematika dan bisa mengembangkan LKPD untuk materi pembelajaran yang lain secara kreatif.

\section{Daftar Rujukan}

Afifah, E. P., Wahyudi, \& Setiawan, Y. (2019). Efektivitas Problem Based Learning Dan Problem Solving Terhadap Kemampuan Berpikir Kritis Siswa Kelas V Dalam Pembelajaran Matematika. Journal of Mathematics Education, Science and Technology, 4(1), 95-107. https://doi.org/10.30651/must.v4i1.2822.

Anggraini, Widy Anwar, Y., \& Madang, K. (2016). Pengembangan Lembar Kerja Peserta Didik (LKPD) Berbasis Learning Cycle 7E Materi Sistem Sirkulasi Pada Manusia Untuk Kelas XI SMA. Jurnal Pembelajaran Biologi, 3(1), 49-57. https://core.ac.uk/download/pdf/267822818.pdf.

Ayazgok, B., \& Aslan, H. (2014). The review of academic perception, level of metacognitive awareness and reflective thinking skills of science and mathematic university students. Procedia - Social and Behavioral Sciences, 141(1), 781-790. https://doi.org/10.1016/j.sbspro.2014.05.137.

Bey, A., \& Asriani. (2013). Penerapan Pembelajaran Problem Solving untuk Meningkatkan Aktivitas dan Hasil Belajar Matematika pada Materi SPLDV. Jurnal Pendidikan Matematika, 4(2), 224-239. https://doi.org/10.36709/jpm.v4i2.2035.

Crismono, P. C. (2017). Pengaruh Outdoor Learning Terhadap Kemampuan Berpikir Kritis Matematis Siswa The Influence Of Outdoor Learning On The Mathematical Critical Thinking Skills Of Students. Junal Pendidikan Matematika Dan Sains, 4(2), 106-113. http://journal.uny.ac.id/index.php/jpms.

Darmawan Harefa. (2020). Pengaruh Model Pembelajaran Problem Solving Terhadap Hasil Belajar IPA Fisika Siswa Kelas IX SMP Negeri 1 Luahagundre Maniamolo Tahun Pembelajaran (Pada Materi Energi Dan Daya Listrik). Jurnal Education and Development, 8(1), 231-234. http://journal.ipts.ac.id/index.php/ED/article/view/1540.

Depdiknas. (2006). Kurikulum Standar Kompetensi Matematika Sekolah Menengah Atas dan Madrasah aliyah. Depdiknas.

Effendi, Refki ., Herpratiwi, \& S. S. (2021). Pengembangan LKPD Matematika Berbasis Problem Based Learning di Sekolah Dasar. Jurnal Basicedu, 5(2), 920-929. https://doi.org/10.31004/basicedu.v5i2.846.

Fimansyah, D. (2015). Pengaruh Strategi pembelajaran dan minat belajar terhadap hasil belajar matematika. Judika (Jurnal Pendidikan UNSIKA), 3(1). https://journal.unsika.ac.id/index.php/judika/article/view/199.

Firli, A., Rismayani, F., Sitorus, P. M. T., \& Manuel, B. (2017). Implementing Mixed Method Of Peer Teaching And Problem Solving On Undergraduate Students. Journal of Education Research and Evaluation, 1(1), 1-5. https://doi.org/10.23887/jere.v1i1.9843.

Fitriyanto, F., Nurhayati, S., \& Saptorin. (2012). Materi Larutan Penyangga Dan Hpridorbolleimsissolving Pada. Chemistry in Education, 1(1), 40-41.

Hamidah, Nur Haryani, S., \& Wardani, S. (2018). Efektivitas Lembar Kerja Peserta Didik Berbasis Inkuiri Terbimbing Untuk Meningkatkan Hasil Belajar Siswa. Jurnal Inovasi

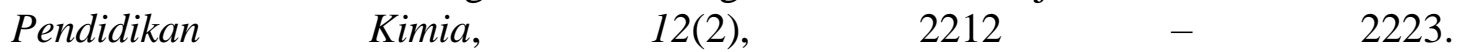
https://journal.unnes.ac.id/nju/index.php/JIPK/article/view/7460.

Handayani, M. W., Swistoro, E., \& Risdianto, E. (2018). Pengaruh Model Pembelajaran Problem Solving Fisika terhadap Kemampuan Penguasaan Konsep dan Kemampuan Pemecahan Masalah Siswa Kelas X MIPA SMAN 4 Kota Bengkulu. Jurnal Kumparan Fisika, 1(3), 36-44. https://doi.org/10.33369/jkf.1.3.36-44. 
Hariawan, H., Kamaluddin, K., \& Wahyono, U. (2014). Pengaruh Model Pembelajaran Creative Problem Solving Terhadap Kemampuan Memecahkan Masalah Fisika Pada Siswa Kelas XI SMA Negeri 4 Palu. JPFT (Jurnal Pendidikan Fisika Tadulako Online), 1(2), 48. https://doi.org/10.22487/j25805924.2013.v1.i2.2395.

Hodiyanto, H. (2017). Pengaruh model pembelajaran problem solving terhadap kemampuan komunikasi matematis ditinjau dari gender. Jurnal Riset Pendidikan Matematika, 4(2), 219. https://doi.org/10.21831/jrpm.v4i2.15770.

Jawadiyah, A. (2021). Pengembangan LKPD Berbasis Problem Learning Untuk Melatihkan Keterampilan Berpikir Kritis Pada Materi Larutan Penyangga. Journal of Chemical Education, 10(2), 195-204. https://doi.org/10.25134/jes-mat.v6i1.2543.

Laswadi. (2016). Pendekatan Problem Solving berbantuan Komputer dalam. Al-Jabar: Jurnal Pendidikan Matematika Vol., 6(1), 33-41. https://doi.org/10.24042/ajpm.v6i1.59.

National Council of Teachers of Mathematics. (2000). Principles and Standards for School Mathematics. NCTM.

Nopitasari, D. (2016). Pengaruh Model Pembelajaran Creative Problem Solving (CPS) Terhadap Kemampuan Penalaran Adaptif Matematis Siswa. M A T H L I N E : Jurnal Matematika Dan Pendidikan Matematika, 1(2), 103-112. https://doi.org/10.31943/mathline.v1i2.22.

Nurliawaty, L., Mujasam, M., Yusuf, I., \& Widyaningsih, S. W. (2017). Lembar Kerja Peserta Didik (LKPD) Berbasis Problem Solving Polya. JPI (Jurnal Pendidikan Indonesia), 6(1), 72-81. https://doi.org/10.23887/jpi-undiksha.v6i1.9183.

Pangastuti, W. D. (2021). Pengembangan Lembar Kegiatan Peserta Didik (LKPD) Berbasis Problem Based Learning Untuk Melatih Keterampilan Berpikir Kritis Pada Mata Pelajaran Sejarah Kelas XI IPS DI SMAN 1 Tarik. AVATARA, 10(2). https://ejournal.unesa.ac.id/index.php/avatara/article/view/38665.

Permana, R. H. (2019). Survei Kualitas Pendidikan PISA 2018: RI Sepuluh Besar dari Bawah. detikNews (online). DetikNews.

Prastowo, A. (2016). Panduan Kreatif membuat Bahan Ajar Inovatif. DIVA Press.

Pristiwanto. (2016). Penerapan Metode Pemecahan Masalah (Problem Solving) Untuk Meningkatkan Pemahaman Siswa Tentang Komponen Peta. Jurnal Ilmiah Pendidikan Dan Pembelajaran, 2(2), 127-134. http:/lejurnal.unisda.ac.id/index.php/wahana/article/view/347.

Purwanti, S., \& Manurung, S. (2015). Analisis Pengaruh Model Pembelajaran Problem Solving Dan Sikap Ilmiah Terhadap Hasil Belajar Fisika. Jurnal Pendidikan Fisika, 4(1), 57. https://doi.org/10.22611/jpf.v4i1.2569.

Puspita, L., Supriadi, N., \& Pangestika, A. D. (2018). Pengaruh Model Pembelajaran Creative Problem Solving (CPS) Disertai Teknik Diagram Vee Terhadap Keterampilan Berpikir Kreatif Peserta Didik Materi Fungi Kelas X MAN 2 Bandar Lampung. Biosfer: Jurnal Tadris Biologi, 9(1), 01. https://doi.org/10.24042/biosf.v9i1.2871.

Ristiasari, T., Priyono, B., \& Sukaesih, S. (2012). Model Pembelajaran Problem Solving Dengan Mind Mapping Terhadap Kemampuan Berpikir Kritis Siswa. Journal of Biology Education, 1(3), 34-41. https://doi.org/10.15294/jbe.v1i3.1498.

Salim Nahdi, D., \& Cahyaningsih, U. (2018). Pengembangan Perangkat Pembelajaran Matematika Sd Kelas V Dengan Berbasis Pendekatan Saintifik Yang Berorientasi Pada Kemampuan Pemecahan Masalah Siswa. Jurnal Cakrawala Pendas, 5(1). https://doi.org/10.31949/jcp.v5i1.1119.

Sasmito, L. F., \& Mustadi, A. (2015). Pengembangan Lembar Kerja Peserta Didik TematikIntegratif Berbasis Pendidikan Karakter Pada Peserta Didik Sekolah Dasar. Jurnal 
Pendidikan Karakter, 5(1), 70-81.

Syazali, M. (2015). Pengaruh Model Pembelajaran Creative Problem Solving Berbantuan Media Maple 11 Terhadap Kemampuan Pemecahan Masalah Matematis. Al-Jabar: Jurnal Pendidikan Matematika, 6(1), 91-98. https://doi.org/10.24042/ajpm.v6i1.58.

Tampubolon, T., \& Sitindaon, S. F. (2013). Pengaruh Model Pembelajaran Problem Solving Terhadap Hasil Belajar Siswa Kelas X SMA Negeri 7 Medan. Jurnal INPAFI, 1(3), 260-268. https://doi.org/10.24114/inpafi.v1i3.1915.

Warimun, E. (2017). Peningkatan Pemahaman Konsep Dan Keterampilan Problem Solving Mahasiswa Melalui Pembelajaran Model Problem Solving Pada Materi Kesetimbangan Benda Tegar. Seminar Nasional Magister Pendidikan Dasar, 113119. 